\title{
The Role Intellectual Property In Achieving Economic Efficiency In The Agrarian Field
}

\author{
Babadjanov Abdirashid Musayevich \\ Candidate Of Economic Sciences, Senior Research Fellow. Associate Professor Of The Department \\ "Accounting And Audit", Tashkent Institute Of Irrigation And Agricultural Mechanization \\ Engineers; Tashkent, Uzbekistan
}

Journal Website:

http://usajournalshub.c om/index,php/tajssei

Copyright: Original content from this work may be used under the terms of the creative commons attributes 4.0 licence.

\section{ABSTRACT}

In the agrarian field, which is one of the leading sectors of the economy of the Republic, a multi-ukladic economy based on various forms of ownership and Economic Conduct has been restored. The development of Agriculture on an innovative basis in the current period, in which the processes of economic development are rapidly developing, the rational and effective use of the formed scientific potential and the created property serves to increase the competitiveness of agricultural enterprises, further strengthen the position of the products grown in the domestic and foreign markets.

The article describes some of the shortcomings encountered in achieving these goals and comments on their elimination and leads to the fact that they have a low indicator in achieving economic efficiency. As a result of the research work carried out, it is necessary to establish innovative projects in the agrarian field, to finance and implement them into practice. It also provides a well-grounded conclusion and a scientific proposal based on the results of the study.

\section{KEYWORDS}

Agrarian field, scientific-research, innovation, intellectual property, economic efficiency, scientific potential, improvement. 


\section{INTRODUCTION}

One of the most important factors of sustainable development of the agricultural sector of the Republic is the transfer of all its branches to the path of modernization and innovative development. In the modernization of agriculture, it is necessary to carry out such activities as the placement of crop varieties taking into account the soil and climatic conditions of each region, the specialization of production, the implementation of scientific and technological innovations in the field of agricultural production, production and economic relations. When modernizing the agrarian sector, updating it only technically, technologically is one of the main reasons for not achieving the expected result. Innovation project is a complex of organizational and legal, financial and economic documents necessary for the implementation of these scientific works in specific enterprises or production entities.

The role and effective use of intellectual property in the agrarian sector and the realization of entrepreneurial potential is one of the important urgent tasks.

Particular attention should be paid to the formation of funds aimed at short-term innovation projects in the Republic, the broad introduction and financing of innovations, as well as the establishment of large-scale indepth cooperation with scientific institutions and production networks.

Alternatively, carrying out research on the essence of intellektual property in agriculture and on this basis the development of strategic directions for the development of intellektual property market will speed up the implementation of the results of scientific and technical development activities into agricultural production, the scientific and technical framework creates conditions for the formation of expanded reproduction and allows maintaining the innovative development policy of the country's economy [1].

In the second half of the last century in developed countries, rapid growth of technical development of science, rapid development of production and service spheres based on scientific work gave a new impetus to the rapid economic growth. New directions of economic growth were formed on the basis of the use of scientific developments and innovations as important economic resources in the world economy.

Intellect in assessing its economic essence as an economic category of real estate, it is primarily worthwhile to dwell on the relationship of ownership. Because, any production is based on any possession in relation to its material factors.

Today, there is also a revival in the process of scientific research on the study of general economic problems of intellectual property.

The belongs to the agrarian sector, intellectual of property economic aspects, its adaptation to the economic process, the economic relations of agricultural property, its appearance, the role and role it occupies, its interaction with other properties, methods of assessing the intangible results of Labor, the fundamentals of the formation of the agricultural market, also, the further development of Agrarian Science in the country on the basis of scientific research of 
strategies for the introduction intellectual property into the economic process is also one of the pressing issues.

The solution of the problems in the agrarian sector creates a basis for the transition of our country's economy to the path of innovative development. It is known that the problem of achieving and maintaining economic efficiency in the agrarian sector is often associated with the reduction in the cost of the production process of the product or the normalization of the expenditure of resources.

Of course, it is wrong to deny the relevance of the task of reducing the consumption of Labor and material and technical resources in the production process. But choosing the direction in which the achievement of production efficiency is associated only with reducing the expenditure of resources, and striving to achieve the goal through this, in our opinion, the only correct way. not saying.

The problem of achieving production efficiency in the network is a complex approach, including the introduction of modern advanced technologies and innovative innovations, is one of the main conditions for the satisfaction of quality and efficiency.

Because the product created by man as a result of the pursuit of innovation, the introduction of the Advanced Idea Into the practice of production increases scientific and technical progress to another level qualitatively. Scientific and technical progress develops primarily in direct harmony with the development of Science [2].

\section{LITERATURE REVIEW}

At present, the issue of using human potential of economic reforms in the agrarian sphere of the country is getting a new look. That is, the sector of the economy, which is new to us, is emerging, in which the results of the activities of specialist scientists as a product, namely, the rights to property are manifested, and the opportunities to receive income from the product of human labor are expanded.

Modern socio-economic development is manifested as the primary factor in the creation of conditions for the formation of advanced educational directions and specialists in the country and the preparation of competitive scientific personnel. Bunda State scientific institutions, business entities holding a specific place, they are required to use the potential to create innovative products purposefully and wisely. In such a case, the probability of the formation of an innovative environment or the emergence of an innovative idea is high.

Many scientists have focused their attention on intellectual property issues.

Professor Vaypan V.A., in his opinion, (2008) "intellektual property concept," intellektual property is the right to own a intellektual product that is legally assigned to the owner of the Copyright" [3].

S. P. Grishaev says so, (2007) "Intellectual product - this is the result of spiritual, intellectual, spiritual activity: inventions, discoveries, patents, scientific reports and reports, projects, technology descriptions, literature, music, includes works of art and works of art" [4]. 
L. Golsberg emphasizes, (2008) “Intellectual property is based on knowledge. Knowledge, this quot; "is a set of truths fixed in the mind and thinking associated with a particular field. Until the moment of fixation on any means, knowledge is inextricably linked with its source-man""' [5].

S.K. According to Shatalov, "intellectual property is a product of creative activity in the sphere of production, scientific, literary, artistic, which has a non-material character. At the same time, intellectual property is included in certain material objects or, together with them, exists as a quality component, commodity price. From this point of view, it itself becomes a kind of product" [6].

V.M. In the studies of Aldoshin and others, (2006) "First of all, one of the approaches that is relevant to the main developers of high - tech technology samples, which will allow the local industry to maintain its high scientific potential, - is a set of activities that include" that emphasizes [7].

E.G. In their research of Lazarevich and others (2007), "The introduction of methods and technologies for the formation and management of the results of manual activities significantly increases the intellectual capacity of industrial firms, ensuring the competitiveness of their products and allowing them to master and maintain the markets with high-tech products. A lot of money is spent on this, resulting in huge profits" [8].

In our opinion, the primary basis for the development of the innovation process is the social environment and the factor of entrepreneurship, on this basis it is necessary to develop innovative ideas, the system of their implementation and implementation.

Intellectual property - is the product of creative mental activity. The right set of inventive and authorship objects includes science, creative activity in the field of production, discoveries, inventions, rationalization proposals, programs for computers, databases, expert systems of know-how, trademarks and other intellectual property objects [9].

Increasing the effectiveness of the use of intellectual property in the agrarian sphere is primarily associated with the development of innovative activity in the network. The organization and development of the scientific supply of the industry is associated with the expansion of scientific research and experimental design work and the introduction of its results into practice. It consists of three important areas: special programs, scientific research and the introduction of scientific research results into practice [10].

The effective use of intellectual property in the development of innovative activity is directly related to the improvement of the system of financing the research work carried out for network development. Because, the peculiarities of Agriculture in relation to other sectors differ with the peculiarities of financing the research work carried out in this network [11].

In the conclusion of such programs in our country, it will be appropriate to pay special attention to ensuring the interdependence of Science with production in the creation of conditions for constant updating of innovative processes technical, biological and chemical substances, technologies and forms of 
The American Journal of Social Science and Education Innovations (ISSN - 2689-100x)

Published: April 30, 2021 | Pages: 611-623

Economic Conduct, adaptation of agricultural production to the requirements of agroclimate factors and market, introduction of world standards.

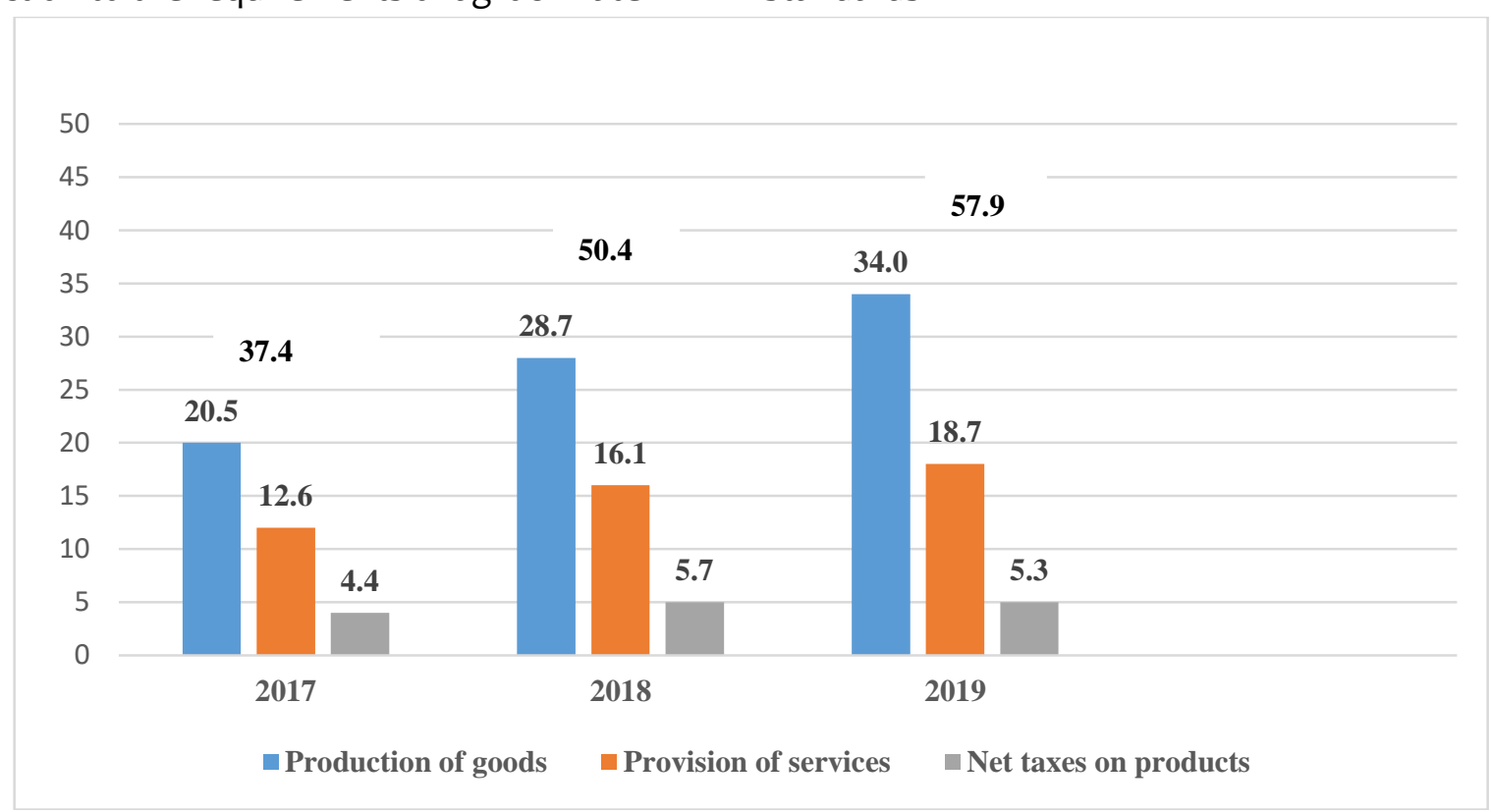

1-picture. In 2017-2019, the volume of gross domestic product of the Republic of Uzbekistan (at current prices, trln. sum) ${ }^{1}$.

All this allows to increase the level of intensification of Agriculture and Reproduction, increase labor productivity, as a result of the introduction of innovation, the formation of additional sources of income in all branches and sectors of the agrarian sector.

According to preliminary data, the volume of gross domestic product of the Republic of Uzbekistan in 2019 amounted to 57.9 billion dollors at current prices and increased by $5.6 \%$ compared to 2018.

By the end of 2019 year, production of goods in the composition of gross domestic product ${ }^{2}$ 34.0 billion. the dollar, in the field provision of services -18.7 billion. in the amount of dollor, gross value added was created, as for the net taxes on products -5.3 billion. dollar made up ni (1-picture).

\footnotetext{
${ }^{1}$ Source: The Republic of Uzbekistan is based on the data of the State Statistics Office.
}

${ }^{2}$ Source: village, forest and fish farm, includes industry and construction. 
1-table.

Growth rates of gross domestic product by types of economic activity in 2017-2019 years (in \% compared to last year) ${ }^{3}$.

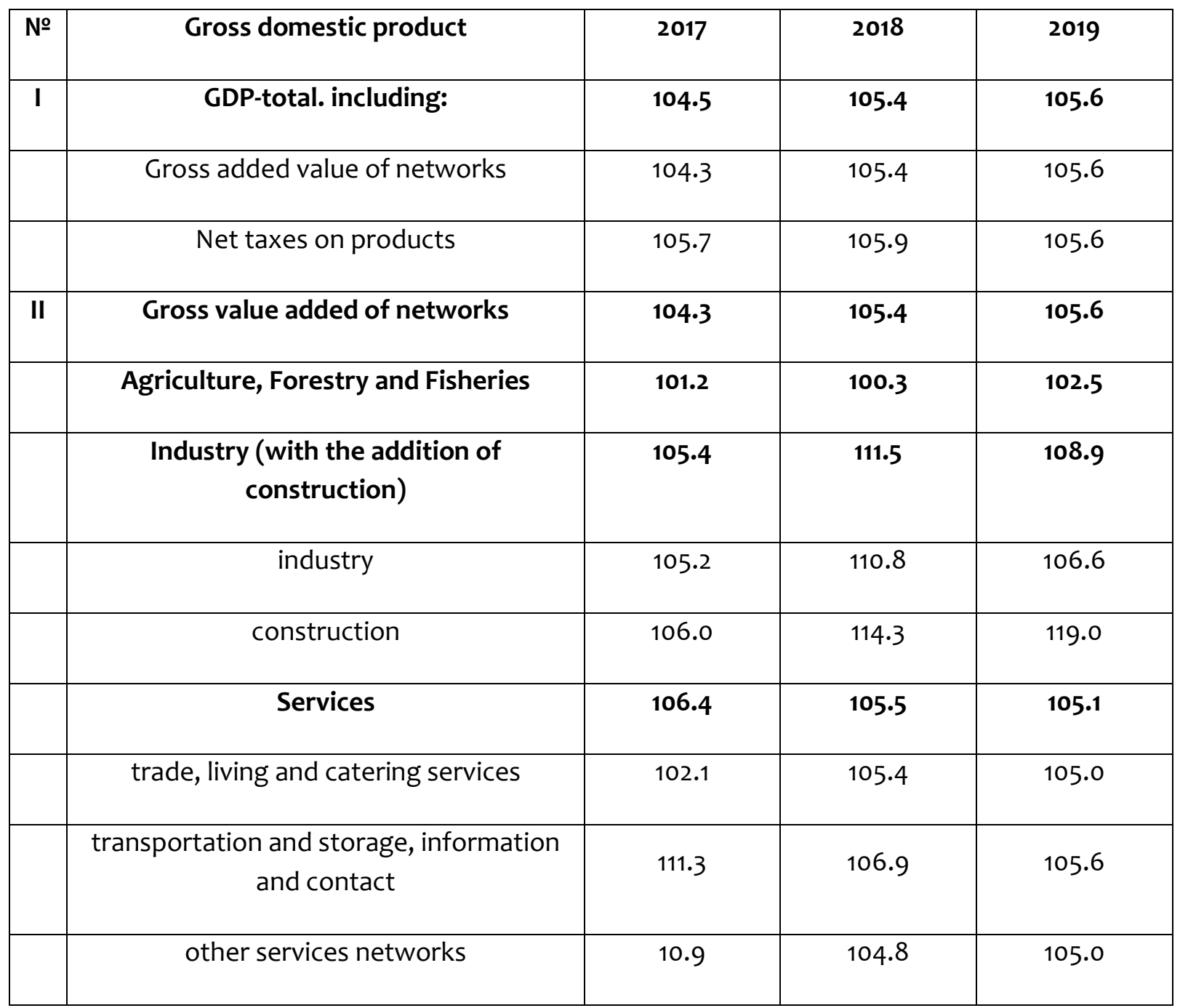

The pace of economic growth in 2019 year is associated with the positive dynamics observed in the main sectors of the economy. The volume of Gross Value-Added created in all sectors of the economy accounted for $90,9 \%$ of the total gross domestic product and increased by $5.6 \%$ (the impact on the absolute growth of gross domestic product was 5.0 percent Punkt). The share of net taxes on products in the composition of gross domestic product was $9,1 \%$, and an increase was recorded at the level of 5,6\%, respectively (the effect of

\footnotetext{
${ }^{3}$ Source: The Republic of Uzbekistan is based on the data of the State Statistics Office.
} 
absolute increase in gross domestic product was 0,6 percent punkt) (1-table).

By the end of 2019, a positive increase was recorded in the level of 2,5\% in agriculture, forestry and Fisheries. The impact of this network on the absolute growth rate of gross domestic product was 0,7 percent Punkt. The rate of positive growth in agriculture, forestry and fish farming is associated with an increase of $3,7 \%$ of the production of farming products and $1,7 \%$ of the production of livestock products (2-picture).
In the innovation process, along with the management structures of the agro-industrial complex, industrial, agricultural and various service enterprises are also involved. Therefore, in order for the ultimate goal to be achieved, it is necessary to determine the requirement of innovation process participants for innovation and to achieve it in relation to each other the stages of development, use and implementation of the result in practice [12].

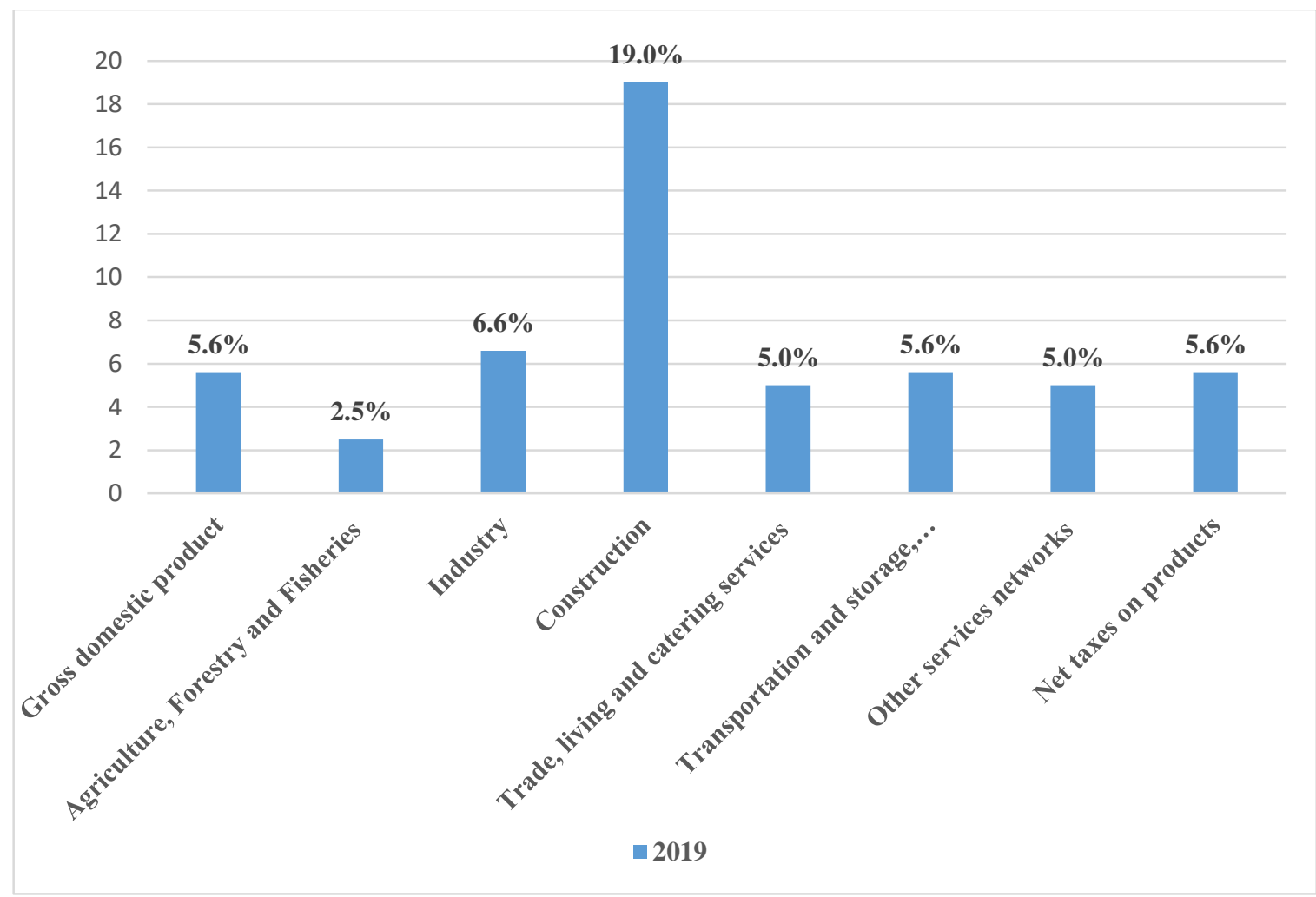

2-picture. Absolute growth rates of gross domestic product by types of economic activity in 2019 year (in \% compared to last year) 4

\footnotetext{
${ }^{4}$ Source: The Republic of Uzbekistan is based on the data of the State Statistics Office.
} 
It is known to everyone that the development of innovative activities in agriculture does not give a good effect to the individual solution of each of the problems.

In our opinion, the country's innovative policy in the agrarian sphere should be recognized as one of the main tasks in the development and implementation of a special state program covering the strategy, directions of modernization of the economy.

In our opinion, the main components of this program should be defined as follows: interaction between scientific institutions, higher education institutions and consumer market entities that create innovations in the field, cooperation based on materialism, organization and development of integration relations; Organization of the "Innovation Development Fund" at the Republican level in order to solve such priority tasks as development of Agriculture on an innovative basis, production of ecologically clean quality agricultural and livestock products meeting international standards, taking a strong place in domestic and foreign markets through export; to bring to the Republic innovative technology and scientific works of the developed foreign countries in the field of Agriculture, to organize a special structure, which includes the subjects engaged in rational application of them in accordance with the natural-climatic and soil conditions of the regions, to develop its status and functions, and to determine the sources of financing; in the development of innovative activities and activities in agriculture, it is necessary to define the directions of further development of the state's coordinating and stimulating role.
And the programs of scientific research, which are in practice at the present time, are fundamental and applied research: the result of fundamental research determines a theoretical new direction of Science; the result of Applied Research becomes a scientific work and determines a new direction of science.

The implementation of Buday programs consists in improving the development system of production technology and agrarian sector. The program of implementation consists in achieving production results in a certain direction on the basis of the introduction into the production of the results of scientific research.

\section{RESEARCH METHODOLOGY}

The system of introduction of new technologies into production in agriculture, the possibility of achieving economic efficiency in the agrarian sector and carrying out the implementation of the results of intellectual property in the network on the basis of a program of practical implementation is clearly indicated. Based on the result of the research, conclusion and scientific suggestions have been developed. In the process of research, scientific knowledge and economic analysis methods have been widely used.

\section{ANALYSIS AND OF RESULTS DISCUSSION}

The system of scientific supply of the agrarian sector includes strengthening the existing scientific potential in it, increasing the level of providing agriculture with qualified and highly qualified personnel, the introduction of effective methods of management, the 
development of opportunities in connection with improving the organizational and economic context of the harmonization of Science and production. For this purpose, the role of intellectual property in the organization and development of innovative activities in agriculture is incomparable, and in the rational and effective use of this property in the network in the conditions of a market economy, it is necessary to ensure a continuous link between the achievements of Science and production, to improve the sources of financing for the development

Increasing the efficiency of agricultural of intellectual property is primarily associated with the development of innovative activity in the field. In order to further enhance the position of intellectual property in the industry, it is necessary to accelerate the process of scientific research and its implementation in practice. The organization and development of scientific supply of the agrarian sector is also associated with the expansion of scientific research and experimental design work and the introduction of scientific results into practice.

The analysis shows that the development of each country is determined by the level of use of scientific potential and the management of production on a scientific basis, first of all, in the development of the economy, no matter what kind of economic system this state is in. Because science, scientific institutions, scientists and employees of science have always had a direct impact on the social economic development of society with their new ideas and ideas. In this respect, the development of ingenuity, the arrival on the field of major inventions and discoveries in one direction are important factors of innovation.
Also, the product created by man as a result of the pursuit of innovation, the introduction of the advanced idea into the production process will increase the scientific and technical development qualitatively to another level. Scientific and technical progress is carried out, first of all, directly in conjunction with the development of science.

The main product in the agricultural sector is to determine the effective use of intellectual property and its scientific and practical directions in the development of innovative processes and the rapid introduction of innovation activities in the manufacturing entities.

As a result of our research, it is important to note that the rapid introduction of innovation product in agriculture directly correlates to how property is formed and to its extent. Due to this, it is important to improve the quality of production of products (services), to organize and develop processes in a complex way.

Therefore, the process of innovation and innovation arises from the need to determine the essence of each of them, based on the principle of uniqueness to the economic categories of intellektual property and intellektual potential, to define the cases of interdependence and influence from the scientific and theoretical standpoint and to base its classification characteristics.

With the transition from a planned economic system to a market-specific economy, there is a decrease in the role of the state in the sectors of the economy, and management methods characteristic of market principles are widely introduced. There is a development of business entities, forms and types of services offered by 
them, which are consistent with the principles of market economy. In addition to the creation of scientific and technical products in institutions with the participation of the state and with the support of scientific research, entrepreneurial subjects are developing, they are also developing a system of creating scientific products or innovative products.

While this practice has been taking shape in developed countries for several decades, our republic is developing after the independence period. In the economy, however, there are laws that govern its movement, as well as underground acts of law, normative acts, special state and commercial bodies that are formed, after which it will be difficult to imagine the socio-economic development of society without them.

The practical formation of the innovation process is as follows: the development of society or a favorable social environment; the development of modern science and technology in the country; the level of investment or capital orientation; the level of investment or capital orientation; the formation of qualified personnel and specialists; institutions and business entities; the innovation environment or innovation idea; intellectual property or product; market factor.

Innovation develops in a way that is closely connected with the development of society. For this, first of all, we think that a favorable environment should be formed in the country itself to a certain extent. The way of modern socio-economic development of society, the creation of conditions for the formation of advanced directions of education and specialists in the country, as well as the development of competitive personnel are first manifested as the primary factor. For this, however, avvlo is required to have a certain level of financial resources or investment. These investments play an important role in the development of personnel or competitive specialists.

After the formation of highly qualified specialists, it will be necessary to create a favorable environment for its use, as well as the formation of a team that creates innovative products. Bunda State scientific institutions, business entities occupy a special place and they are required to make reasonable use of qualified personnel for the socio-economic development of society, for the creation of the product necessary for the market in a certain circle. In such a case, the probability of the formation of an innovative environment or the emergence of an innovative idea is high. And the idea of innovation can be formed as a result of the human factor after a certain period of time as the intellektual property of a particular person or a particular community. Intellekt the object of real estate, however, in this view, can also become a necessary product for the society or for some subject, or vice versa, which may not be of interest. In such circumstances, the demand for a product or its market factor plays an important role. If the buyers of the product offer a certain value for it, or if they are in demand to purchase it, then it can become an innovative commodity. As for the innovation product, after its value is partially or completely given, it can be directed to production and lead to the beginning of the innovation process.

In our opinion, the primary basis for the development of the innovation process is the social environment and the factor of entrepreneurship, and on this basis innovative 
ideas and the system of application is organized.

Socio-economic development of society, investment or capital directed to the creation of intellectual property, human resources, innovation, intellectual property and innovation processes take place and develop in accordance with the principle of interdependence. At the same time, these processes serve as a basis for the development of each other in accordance with the principle of interaction in the field of social production (services). The direction of development carried out in a particular industry or field, for example in the field of technology, creates new demands on innovative products or innovative developments due to the tendency to wear out both physically and spiritually after a certain period.

As a result, the transformation of intellectual property into a commodity, davriy turnover under the growth trend of its quality and efficiencyadorlik levels occurs, and this process is repeated without interruption in accordance with the principle of continuity, depending on the characteristics of each network and sphere. This process also provides the basis for the organization of expanded reproduction in all sectors and sectors of the economy, and serves to strengthen the material and technical base of increasing their production, economic and export potential.

In our opinion, we consider innovation - as a process, and from this it is necessary to solve the problems associated with it within the framework of a holistic system [13].

The effective use of intellectual property in the development of innovative activity in the agrarian sector is directly related to the improvement of the system of financing the research work carried out for network development. Because, the peculiarities of the agricultural network in relation to other sectors differ with the peculiarities of financing the research work carried out in this network [14].

Innovation in the agrarian sphere is an indicator of its economic essence, from ensuring the interdependence of Science with production in the creation of conditions for the introduction of world standards in the production of technical, biological and chemical substances, technologies and forms of Economic Conduct, adaptation of agricultural production to the requirements of agroclimate factors and the market, as well as the introduction

All this allows to increase the level of intensification of agricultural and processing production, increase labor productivity, as a result of the introduction of innovation, the formation of additional sources of income in all branches and sectors of the agrarian sector.

\section{SUMMARY AND SUGGESTION}

As a result of the research carried out in the agricultural sector, the conclusion based on the development of the agrarian sector, the role of intellectual property, the effective use of intellectual property, the conclusion based on the drafting and implementation of innovative projects, the analysis of issues related to intellectual property based and scientific proposal developed.

As a result of the research carried out within the framework of the topic, the main issues related to intellectual property in the sectors of 
the economy of the agrarian sector were studied.

Innovation and high-tech products in the agrarian sector can lead to drastic changes in the economy of the Republic, eliminating the problems that are inextricably linked toualual property. At present, the country needs change and transformation of economic sectors and plays a key role in this process intellektual property. If intellectual property can influence the competitiveness of agricultural enterprises, it will also affect the economic sectors of the country as a whole. Intellectual property not only contributes to the increase in GDP and other economic indicators, but also radically changes the direction of economic developmenttirib and also changes its structure.

As a result of the study, the following based conclusion was developed.

In our view, it is desirable to take into account the following factors in the effective organization of scientific supply of the agrarian sector:

- Selection of priority topics of practical and innovative research based on existing problems in agriculture;

- To carry out scientific research in the framework of practical problems of the agrarian sector in proportion to the fundamental and practical research directions;

- Implementation of completed practical research results in the form of innovative projects;

- Formation of new directions of agrobiznes on the basis of taking into account the Real demand of agricultural enterprises and of course the experience and skills of introducing innovations in the implementation of innovative projects on solutions of urgent problems and ensuring their direct participation.

In the development of innovative activities in the agrarian sphere, the following scientific proposal was developed aimed at the role and use ofualual property.

The following state support for innovative activities in agriculture should be used:

- Creation and infrastructure of support for innovative activities within the framework of innovative policy direction;

- Selection of innovative projects and scientific research on the basis of competition in order to ensure the formation of innovative projects and each of them will pass the stage of test design work;

- Organization of selection based on the recognition of projects aimed at the development of innovative infrastructures;

- Development of personnel capacity of innovation activity, professional development and retraining of personnel in the field of innovation, including specialists within the framework of innovation management, using the existing training infrastructure in the country.

\section{REFERENCES}

1. Babadjanov A.M. (2011) Effective use of scientific cum technologically achievements and financing innovative projects in the agricultural sphere. Journal. «Agricultural Sciences», USA., Vol. 2, No. 1, 28-33. 
2. Ushachev I. (2006) "Scientific support of state programs for the development of agriculture in Russia". Moscow. - 9 p.

3. Vaypan V. A., Lyubimov A. P. (2008) New regulation of protection of intellectual property rights. Journal. Law and Economics. Moscow. - No. 1. - Pp. 25-30.

4. Grishaev S. P. (2007) Legal protection of works of science, literature and art as objects of copyright under the new legislation of the Russian Federation. Moscow. VLADOS Humanitarian Publishing Center, $170 \mathrm{p}$.

5. Golsberg L., Kitova G., Kuznetsova T. (2008) "Strategy of integration of processes in the sphere of science and education" Journal. Economic issues. Moscow. - No. 7. 25 p.

6. Shatalov S. K., Source: https: Journal. Center-yf.ru/data/Yuristu/intellektualnayasobstvennost-eto.php

7. Aldoshin V. M., Mokryshev V. V., Mokryshev SV. (2006) Methodological bases for evaluating the efficiency of hightech companies ' knowledge-intensive business. Moscow. INIT "PATENT". 12 p.

8. Lazarevich E. G., Kolganov S. K., Semashko A. N. (2007) Technological basis for ensuring military security of the state. Journal. Science and military security. Moscow. - No. 2. - Pp. 32-36.

9. Sandu I. S. (2009) Activation of innovative activity in the agro-industrial complex. Journal. Agro-industrial complex: economy, management. Moscow. - No. 10. - Pp. 73-79.

10. Babadjanov A.M. (2020) Scientific basis of price determination on a scientific product based on the results of research work in the agrarian sector. Journal. Economics and education. Tashkent. - № 3. - Pp. 231236.
11. Babadjanov A.M. (2020) scientific basis for effective use ofualual property in the development of innovation processes in the agrarian sector. Journal. Agro ScienceAgriculture and water management of Uzbekistan. -№ 2. - Pp. 119-120.

12. Babadjanov A.M. (2020) Investment in the Water Supply and Economic Problems: Solutions. Journal of Scientific Research Reports. India. No. 26(6): -Pp. 100-109.

13. Babadjanov A.M. (2013) Agricultural research for development: investing in Uzbekistan's future. Journal: “Agricultural Sciences", USA.: Vol. 4, No.2, - Pp. 62-65.

14. Babadjanov A.M. (2012) Development of the production of science-intensive products and the use of scientific ideas in the agricultural sector of Uzbekistan. W: "Innovative development of the Russian economy" - Omsk: Publishing House of OmSTU. - Pp. 26-29. 